\title{
Clinical Performance of a New Biomimetic Double Network Material
}

\author{
Christine Dirxen, Uwe Blunck and Saskia Preissner*
}

Charité - Universitätsmedizin Berlin, Department of Operative and Preventive Dentistry, Assmannshauser Straße 4-6,
14197 Berlin, Germany

\begin{abstract}
Background: The development of ceramics during the last years was overwhelming. However, the focus was laid on the hardness and the strength of the restorative materials, resulting in high antagonistic tooth wear. This is critical for patients with bruxism.
\end{abstract}

Objectives: The purpose of this study was to evaluate the clinical performance of the new double hybrid material for noninvasive treatment approaches.

Material and Methods: The new approach of the material tested, was to modify ceramics to create a biomimetic material that has similar physical properties like dentin and enamel and is still as strong as conventional ceramics.

Results: The produced crowns had a thickness ranging from 0.5 to $1.5 \mathrm{~mm}$. To evaluate the clinical performance and durability of the crowns, the patient was examined half a year later. The crowns were still intact and soft tissues appeared healthy and this was achieved without any loss of tooth structure.

Conclusions: The material can be milled to thin layers, but is still strong enough to prevent cracks which are stopped by the interpenetrating polymer within the network. Depending on the clinical situation, minimally- up to non-invasive restorations can be milled.

Clinical Relevance: Dentistry aims in preservation of tooth structure. Patients suffering from loss of tooth structure (dental erosion, Amelogenesis imperfecta) or even young patients could benefit from minimally-invasive crowns. Due to a Vickers hardness between dentin and enamel, antagonistic tooth wear is very low. This might be interesting for treating patients with bruxism.

Keywords: CAD/CAM, Enamic, double network hybrid material, non-invasive treatment, dental erosion, bruxism.

\section{INTRODUCTION}

Since there is a great variety of dental ceramics and a large selection of composite resin materials on the market, it is questionable why there is a need for a new material. Table 1 lists important parameters to compare zirconia, feldspar, lithium-disilicate and composite resins with each other. Advantages of ceramics are a high flexural strength and a great color stability, while disadvantages are high antagonistic tooth wear and loss of tooth structure due to a minimum thickness of 1.5 to $2.0 \mathrm{~mm}$. These two parameters are better for composite resins, but the wear of the material itself is higher. The table also lists Youngs modulus and Vickers hardness for dentin and enamel. While ceramics are stiffer and harder than natural tooth structure, composite resins show lower values. These parameters show that there is a need for a material that combines the advantages of ceramics with those of composites with the focus on the prevention of natural tooth structure. Therefore Youngs modulus should come close to dentin, hardness should be between enamel

*Address correspondence to this author at the Charité - Universitätsmedizin Berlin, Department of Operative and Preventive Dentistry, Assmannshauser Straße 4-6, 14197 Berlin, Germany; Fax +49 30450562 932;

E-mail: saskia.preissner@charite.de and dentin. A minimum of wear of both the material itself and the antagonistic tooth, would be desirable and the most important requirement for a new material would be a very low minimum thickness to preserve sound tooth structure.

The new VITA ENAMIC material combines the properties of ceramic and polymer. It consists of a hybrid structure with two interpenetrating networks of ceramic and polymer, a so-called double network hybrid (DNH). Table $\mathbf{1}$ also offers all parameters of ENAMIC compared to those of groups of materials available on the market. Due to the fine structure of feldspar ceramic and the acrylate polymer network, this material has a similar abrasion, high flexural strength and an elasticity close to dentin. The Vickers hardness was evaluated with values between those for dentin and enamel. Wear is comparable to common dental ceramic, while antagonistic tooth wear is lower at the same time. For the preservation of tooth structure the material can be milled very thin $(0.2$ $0.5 \mathrm{~mm}$; VITA Zahnfabrik). The Weibull modulus, which describes the range of fracture, the reliability and strength of a material, is surprisingly high. Fig. (1) shows a SEM micrograph of a Vickers hardness test on a ceramic on the left side (Mark II, VITA Zahnfabrik). The typical crack line is clearly visible. The same test was performed with the hybrid ceramic on the right side. The crack line is is stopped by the interpenetrating polymer within the hybrid network. Accord- 
Table 1. Comparison of Important Parameters of Zirconia, Feldspar, Lithium-disilicate, Composite Materials and ENAMIC. References are given in Parentheses

\begin{tabular}{|c|c|c|c|c|c|c|c|}
\hline & Unit & Dentin & Enamel & Zirconia & Feldspar & Composites & ENAMIC \\
\hline Flexural strength & $\mathrm{MPa}$ & $\begin{array}{l}<207 \\
{[6-8]}\end{array}$ & $\begin{array}{c}<180 \\
{[9,10]}\end{array}$ & $\begin{array}{c}<620 \\
{[11-13]}\end{array}$ & $\begin{array}{c}<150 \\
{[13,14]}\end{array}$ & $\begin{array}{c}<135 \\
{[15-17]}\end{array}$ & $\begin{array}{l}150 \\
{[2]}\end{array}$ \\
\hline Weibull modulus & 1 & I & I & $\begin{array}{c}4-14 \\
{[18,19]}\end{array}$ & $\begin{array}{c}6-23 \\
{[13,20]}\end{array}$ & $\begin{array}{c}<13 \\
{[21,22]}\end{array}$ & $\begin{array}{l}20 \\
{[2]}\end{array}$ \\
\hline Youngs modulus & $\mathrm{GPa}$ & $\begin{array}{c}<25 \\
{[23-25]}\end{array}$ & $\begin{array}{c}<94 \\
{[23,24]}\end{array}$ & $\begin{array}{c}<400 \\
{[26,27]}\end{array}$ & $\begin{array}{c}>50 \\
{[20,26]}\end{array}$ & $\begin{array}{l}<17 \\
{[28]}\end{array}$ & $\begin{array}{l}30 \\
{[2]}\end{array}$ \\
\hline Vickers hardness & $\mathrm{GPa}$ & $\begin{array}{c}<1 \\
{[23-25]}\end{array}$ & $\begin{array}{c}<6 \\
{[24,25,29]}\end{array}$ & $\begin{array}{c}10-12 \\
{[12,27,30]}\end{array}$ & $\begin{array}{l}>6 \\
{[31]}\end{array}$ & $\begin{array}{c}<6 \\
{[28,32]}\end{array}$ & $\begin{array}{l}2.5 \\
{[2]}\end{array}$ \\
\hline Wear & $\mu \mathrm{m}$ & I & I & $\begin{array}{c}<1 \\
{[33,34]}\end{array}$ & $\begin{array}{l}<1 \\
{[14]}\end{array}$ & $\begin{array}{c}>20 \\
{[35,36]}\end{array}$ & $\begin{array}{l}>1 \\
{[37]}\end{array}$ \\
\hline Antagonistic wear & $\mu \mathrm{m}$ & I & I & $\begin{array}{c}84 \\
{[34,38]}\end{array}$ & $\begin{array}{c}53 \\
{[39]}\end{array}$ & $\begin{array}{c}<10 \\
{[40,41]}\end{array}$ & $\begin{array}{c}28 \\
{[37]}\end{array}$ \\
\hline Color stability & $\mathrm{dE}$ & I & I & $\begin{array}{c}<1 \\
{[42,43]}\end{array}$ & $\begin{array}{c}<1 \\
{[44,45]}\end{array}$ & $\begin{array}{c}>2 \\
{[46,47]}\end{array}$ & $\begin{array}{c}<1 \\
{[37]}\end{array}$ \\
\hline Min. thickness & $\mathrm{mm}$ & I & I & $\begin{array}{c}>0.5 \\
{[48,49]}\end{array}$ & $\begin{array}{c}>1.0 \\
{[50-52]}\end{array}$ & $\begin{array}{c}\text { No } \\
{[53,54]}\end{array}$ & $>0.2$ \\
\hline
\end{tabular}
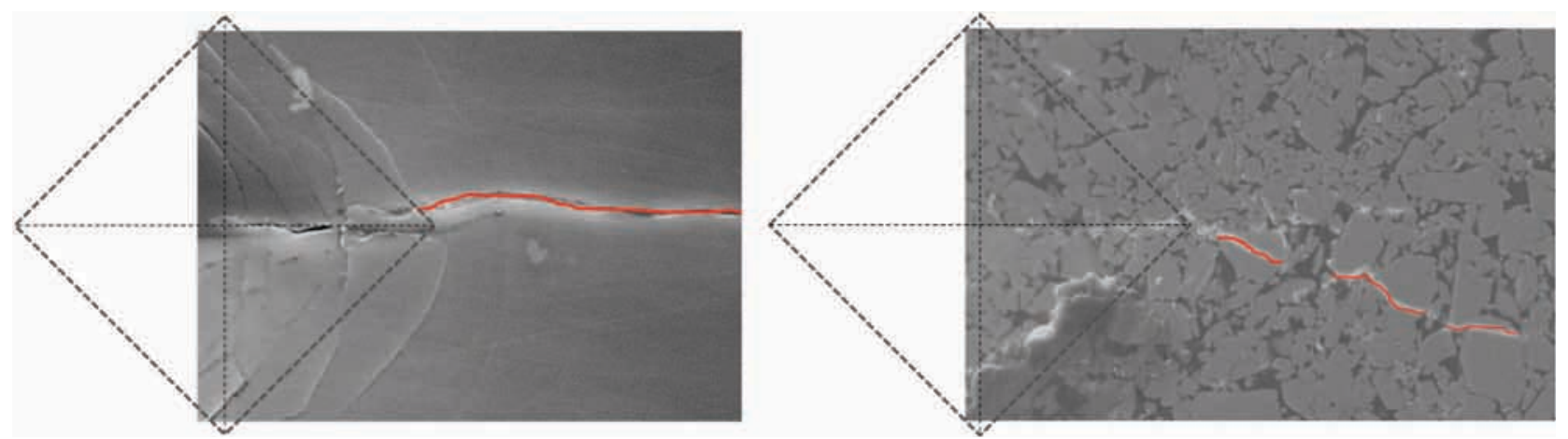

Fig. (1). Vickers hardness: SEM micrographs of Vickers hardness tests of ceramics (Mark II) on the left side and ENAMIC on the right side. The ceramic shows a typical crack line, while the crack line of ENAMIC is thinner and hard to find.

ing to the manufactorer's instructions the material can be used for single crowns. The purpose of this study was to evaluate the clinical performance of ENAMIC for a noninvasive treatment approach of severe dental erosions.

\section{MATERIALS AND METHODOLOGY}

A 36-year-old female patient came to our department consulting us because of her teeth, that were extensively eroded due to gastroesophageal reflux disease as can been seen at the palatal area in the upper jaw and the buccal area in the lower jaw (Fig. 2).

She suffered from dental sensitivity and poor esthetics. There was a loss of occlusal vertical dimension of about 3 $\mathrm{mm}$. Splints were used to increase the vertical dimension from 1.5 to $3 \mathrm{~mm}$ requiring six months. Without any preparation, impressions of the upper and lower jaws were taken using Dimension Penta H (3M Espe, Neuss, Germany) and
Honigum Light (DMG, Hamburg, Germany). Interocclusal as well as laterotrusion and mediotrusion records were obtained. The models were scanned by a Cerec 3D camera to obtain an optical impression based on the stone model. From the virtual model and using Sirona In-Lab, V 3.10, dental database design mode, full coverage restorations were designed and milled from VITA ENAMIC blocks (VITA Zahnfabrik, Bad Säckingen, Germany). The produced crowns had a thickness ranging from 0.5 to $1.5 \mathrm{~mm}$. At the try-in, marginal fit and interproximal contact points were checked carefully before insertion. The operation field was isolated using OptraGate (Ivoclar Vivadent), cotton rolls and high-velocity suction. Two crowns in both upper quadrants (one on the first premolar and one on the molar) were cemented simultaneously in order to guarantee a balance of occlusal contacts. The surfaces intended for bonding were sandblasted with $50 \mu \mathrm{m}$ aluminum oxide powder (Microetcher Danville, 2 bars) and then cleaned with $37 \%$ phos- 


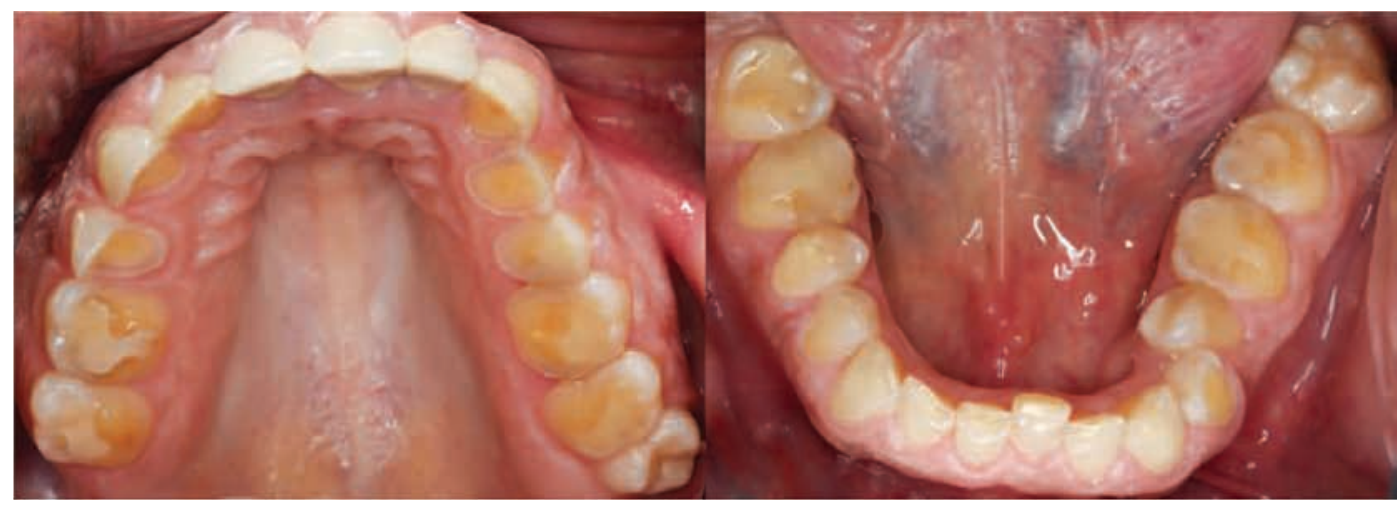

Fig. (2). Initial situation: Upper (left) and lower jaw (right) at the initial situation. Severe loss of tooth structure due to anorexia nervosa.

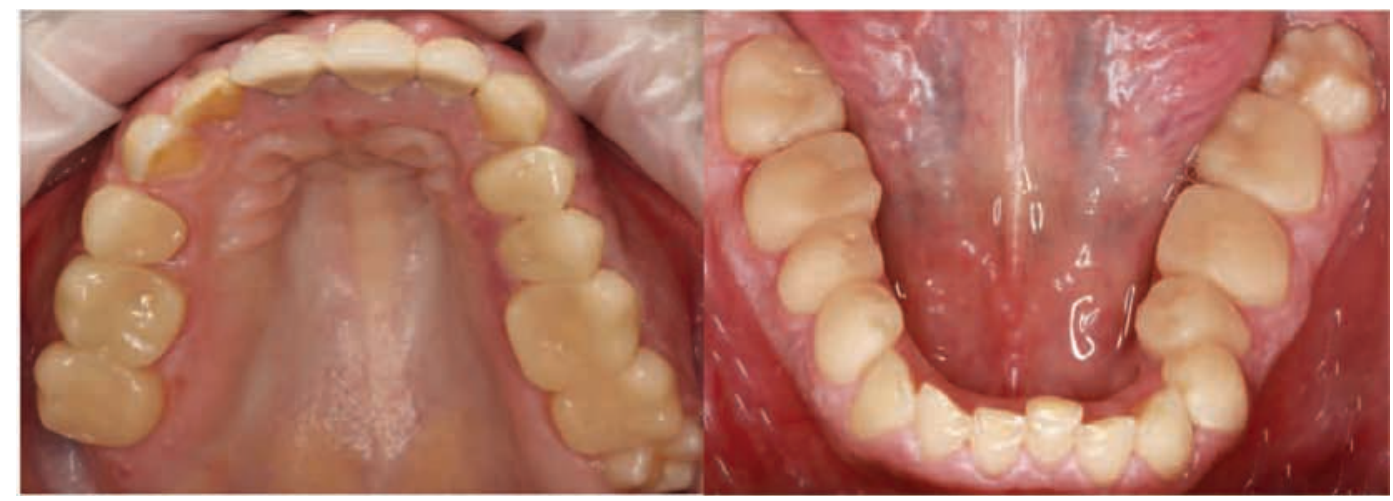

Fig. (3). Final situation: Upper (left) and lower jaw (right) at the first recall after insertion of ENAMIC crowns.

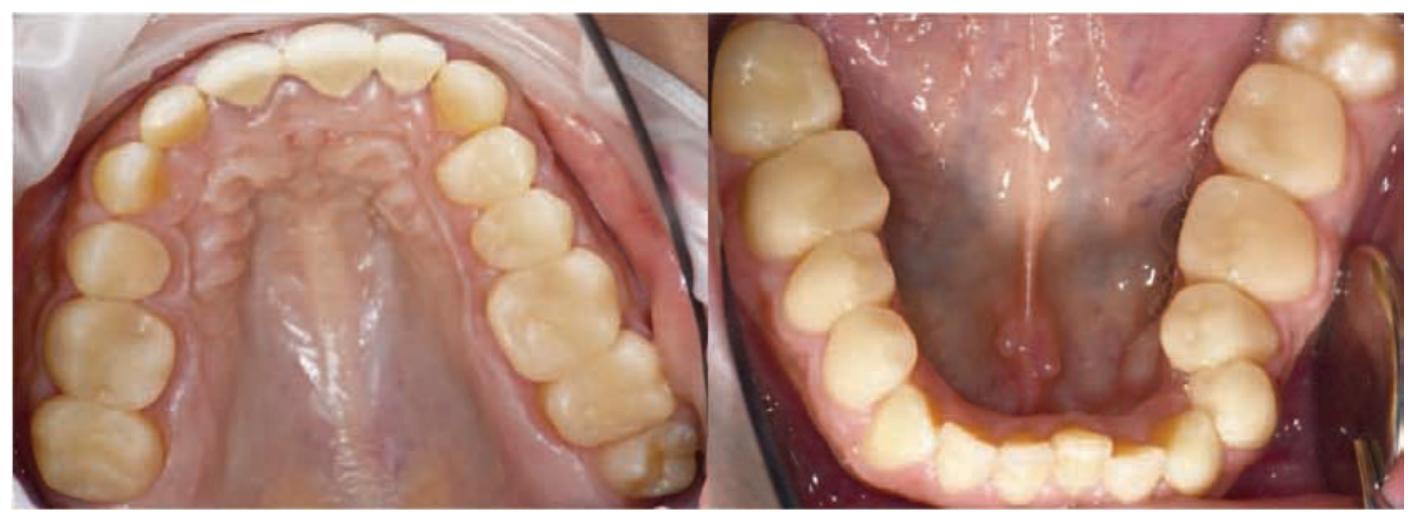

Fig. (4). Recall situation: Upper (left) and lower jaw (right) at the second recall after insertion.

phoric acid for 20 seconds. A two-component adhesive: OptiBond FL (Kerr Dental, Rastatt, Germany) was used on both tooth and restoration surfaces. Following air thinning, the adhesive on the teeth was light-cured. A thin layer of Variolink II A2 (Ivoclar Vivadent) was brushed into the crowns that were subsequently seated immediately intraorally. The restorations were light-cured for $60 \mathrm{~s}$ from each side. Margins were finished with a micropreparation diamond (Komet/Brasseler, Lemgo, Germany) and polishing disks. Occlusal contacts were checked carefully with occlusal adjustment foil. The crowns for the second premolar and molar were inserted similarly paying special attention to the interproximal contact points. The same procedure was repeated for the lower jaw and anterior teeth were adapted to the new situation using composite resin (Tetric Ceram A3, Ivoclar Vivadent). The patient was examined two weeks later (Fig. 3). All crowns were intact, soft tissues appeared healthy, no discolorations to observe so far and this was achieved with no loss of tooth structure. The patient was satisfied with the treatment.

\section{RESULTS}

To evaluate the clinical performance and durability of the crowns, the patient was examined half a year later (Fig. 4 and 5) and one year later. The crowns were still intact and soft tissues appeared healthy. The photos were taken prior to cleaning the teeth. No discolorations were evaluated but plaque accumulation at the cervical margins was visible.

\section{DISCUSSION}

Esthetic and functional rehabilitation are always associated with ceramic restorations. Therefore it is necessary to remove healthy tooth structure to achieve a shoulder/chamfer 


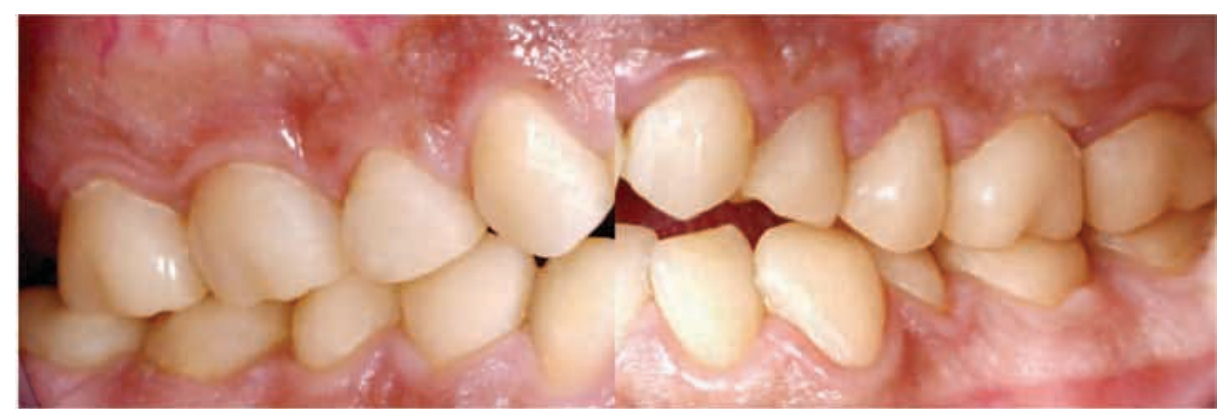

Fig. (5). Recall situation: Right and left side at the second recall after insertion.

and a circular minimum thickness of $1.5 \mathrm{~mm}$. In some cases composite materials can be used, but it takes a lot of valuable chair-time and porosities are likely to appear [1]. To overcome these problems, new CAD/CAM materials have been developed in the last years and there are several polymerinfiltrated-ceramic-network materials (PICN) on the market now [2]. PICN materials have mechanical properties that imitate natural teeth, which is a new approach in restorative dentistry. Youngs modulus is close to dentin, Vickers hardness lies between enamel and dentin. These materials can be milled to thin layers, but are still strong enough to prevent cracks which are stopped by the interpenetrating polymer within the network. Depending on the clinical situation, minimally- up to non-invasive restorations can be milled. Therefore, PICN materials might be interesting for treating younger patients [3], patients suffering from hereditary diseases, such as Amelogenesis imperfecta [4] or patients with bruxism or dental erosions [5].

Since these materials are new on the market, long-term in-vivo studies are still in progress. The shade range is limited and there is no information on the durability regarding cervical areas or discolorations. Nevertheless, novel PICN materials are promising and further research should be performed.

\section{CONFLICT OF INTEREST}

The authors confirm that this article content has no conflicts of interest.

\section{ACKNOWLEDGEMENTS}

The authors would like to thank Schilles/Hütten dental laboratory for their excellent work.

\section{REFERENCES}

[1] Attin T, Filli T, Imfeld C, Schmidlin PR. Composite vertical bite reconstructions in eroded dentitions after 5.5 years: a case series. $\mathrm{J}$ Oral Rehabil 2012; 39: 73-9.

[2] Coldea A, Swain MV, Thiel N. Mechanical properties of polymerinfiltrated-ceramic-network materials: official publication of the Academy of Dental Materials. Dent Mater 2013; 29: 419-26.

[3] Alonso V, Caserio M. A clinical study of direct composite fullcoverage crowns: long-term results. Oper Dent 2012; 37: 432-41.

[4] Preissner S, Kostka E, Blunck U. A noninvasive treatment of amelogenesis imperfecta. Quintessence Int 2013; 44: 303-5.

[5] Guth JF, Almeida ESJS, Ramberger M, Beuer F, Edelhoff D. Treatment concept with CAD/CAM-fabricated high-density polymer temporary restorations. J Esthet Restor Dent 2012; 24: 310-8.

[6] Hayashi M, Koychev EV, Okamura K, et al. Heat treatment strengthens human dentin. J Dent Res 2008; 87: 762-6.
[7] Plotino G, Grande NM, Bedini R, Pameijer CH, Somma F. Flexural properties of endodontic posts and human root dentin : official publication of the Academy of Dental Materials. Dent Mater 2007; 23: 1129-35.

[8] Vieira C, Silva-Sousa YT, Pessarello NM, Rached-Junior FA, Souza-Gabriel AE. Effect of high-concentrated bleaching agents on the bond strength at dentin/resin interface and flexural strength of dentin. Braz Dent J 2012; 23: 28-35.

[9] Bechtle S, Ozcoban H, Lilleodden ET, et al. Hierarchical flexural strength of enamel: transition from brittle to damage-tolerant behaviour. J R Soc Interface 2012; 9: 1265-74.

[10] Ghavamnasiri M, Abedini S, Mehdizadeh Tazangi A. Effect of different time periods of vital bleaching on flexural strength of the bovine enamel and dentin complex. J Contemp Dent Pract 2007; 8: 21-8.

[11] Chen YM, Smales RJ, Yip KH, Sung WJ. Translucency and biaxial flexural strength of four ceramic core materials : official publication of the Academy of Dental Materials. Dent Mater 2008; 24: 1506-11.

[12] Guazzato M, Albakry M, Swain MV, Ironside J. Mechanical properties of In-Ceram Alumina and In-Ceram Zirconia. Int J Prosthodont 2002; 15: 339-46.

[13] Tinschert J, Zwez D, Marx R, Anusavice KJ. Structural reliability of alumina-, feldspar-, leucite-, mica- and zirconia-based ceramics. J Dent 2000; 28: 529-35.

[14] Giordano R. Materials for chairside CAD/CAM-produced restorations. J Am Dent Assoc 2006; 137 Suppl: 14S-21S.

[15] Fischer J, Roeske S, Stawarczyk B, Hammerle CH. Investigations in the correlation between Martens hardness and flexural strength of composite resin restorative materials. Dent Mater J 2010; 29: 188-92.

[16] Ilie N, Hickel R. Macro-, micro- and nano-mechanical investigations on silorane and methacrylate-based composites: official publication of the Academy of Dental Materials. Dent Mater 2009; 25: 810-9.

[17] Leprince J, Palin WM, Mullier T, Devaux J, Vreven J, Leloup G. Investigating filler morphology and mechanical properties of new low-shrinkage resin composite types. J Oral Rehabil 2010; 37: 36476.

[18] Tinschert J, Natt G, Mohrbotter N, Spiekermann H, Schulze KA. Lifetime of alumina- and zirconia ceramics used for crown and bridge restorations. J Biomed Mater Res B Appl Biomater 2007; 80: 317-21.

[19] Yilmaz H, Aydin C, Gul BE. Flexural strength and fracture toughness of dental core ceramics. J Prosthet Dent 2007; 98: 120-8.

[20] Lin CL, Chang YH, Pa CA. Estimation of the risk of failure for an endodontically treated maxillary premolar with MODP preparation and CAD/CAM ceramic restorations. J Endod 2009; 35: 1391-5.

[21] Lohbauer U, Muller FA, Petschelt A. Influence of surface roughness on mechanical strength of resin composite versus glass ceramic materials: official publication of the Academy of Dental Materials. Dent Mater 2008; 24: 250-6.

[22] Manojlovic D, Radisic M, Vasiljevic T, Zivkovic S, Lausevic M, Miletic V. Monomer elution from nanohybrid and ormocer-based composites cured with different light sources: official publication of the Academy of Dental Materials. Dent Mater 2011; 27: 371-8.

[23] Kinney JH, Balooch M, Marshall SJ, Marshall GW, Jr., Weihs TP. Hardness and Young's modulus of human peritubular and intertubular dentine. Arch Oral Biol 1996; 41: 9-13. 
[24] Mahoney E, Holt A, Swain M, Kilpatrick N. The hardness and modulus of elasticity of primary molar teeth: an ultra-microindentation study. J Dent 2000; 28: 589-94.

[25] Xu HH, Smith DT, Jahanmir S, et al. Indentation damage and mechanical properties of human enamel and dentin. J Dent Res 1998;77: 472-80.

[26] Fischer H, Dautzenberg G, Marx R. Nondestructive estimation of the strength of dental ceramic materials: official publication of the Academy of Dental Materials. Dent Mater 2001;17: 289-95.

[27] Lazar DR, Bottino MC, Ozcan M, et al. Y-TZP ceramic processing from coprecipitated powders: a comparative study with three commercial dental ceramics: official publication of the Academy of Dental Materials. Dent Mater 2008; 24: 1676-85.

[28] Visvanathan A, Ilie N, Hickel R, Kunzelmann KH. The influence of curing times and light curing methods on the polymerization shrinkage stress of a shrinkage-optimized composite with hybridtype prepolymer fillers: official publication of the Academy of Dental Materials. Dent Mater 2007; 23: 777-84.

[29] Cuy JL, Mann AB, Livi KJ, Teaford MF, Weihs TP. Nanoindentation mapping of the mechanical properties of human molar tooth enamel. Arch Oral Biol 2002; 47: 281-91.

[30] Guazzato M, Albakry M, Ringer SP, Swain MV. Strength, fracture toughness and microstructure of a selection of all-ceramic materials. Part II. Zirconia-based dental ceramics: official publication of the Academy of Dental Materials. Dent Mater 2004; 20: 449-56.

[31] Deng Y, Lawn BR, Lloyd IK. Characterization of damage modes in dental ceramic bilayer structures. J Biomed Mater Res 2002; 63: $137-45$.

[32] Flury S, Hayoz S, Peutzfeldt A, Husler J, Lussi A. Depth of cure of resin composites: is the ISO 4049 method suitable for bulk fill materials? official publication of the Academy of Dental Materials. Dent Mater 2012; 28: 521-8.

[33] Albashaireh ZS, Ghazal M, Kern M. Two-body wear of different ceramic materials opposed to zirconia ceramic. J Prosthet Dent 2010; 104: 105-13.

[34] Rosentritt M, Preis V, Behr M, Hahnel S, Handel G, Kolbeck C. Two-body wear of dental porcelain and substructure oxide ceramics. Clin Oral Investig 2012;16: 935-43.

[35] Palaniappan S, Elsen L, Lijnen I, Peumans M, Van Meerbeek B, Lambrechts P. Three-year randomised clinical trial to evaluate the clinical performance, quantitative and qualitative wear patterns of hybrid composite restorations. Clin Oral Investig 2010;14: 441-58.

[36] Schmage P, Nergiz I, Sito F, Platzer U, Rosentritt M. Wear and hardness of different core build-up materials. J Biomed Mater Res B Appl Biomater 2009; 91: 71-9.

[37] Mormann WH, Stawarczyk B, Ender A, Sener B, Attin T, Mehl A. Wear characteristics of current aesthetic dental restorative CAD/CAM materials: two-body wear, gloss retention, roughness and Martens hardness. J Mech Behav Biomed Mater 2013; 20: 11325 .
[38] Preis V, Behr M, Handel G, Schneider-Feyrer S, Hahnel S, Rosentritt M. Wear performance of dental ceramics after grinding and polishing treatments. J Mech Behav Biomed Mater 2012;10: 13-22.

[39] Krejci I, Lutz F, Reimer M. Wear of CAD/CAM ceramic inlays: restorations, opposing cusps, and luting cements. Quintessence Int 1994; 25: 199-207.

[40] Barkmeier W, Erickson R, Latta M, Wilwerding T. Wear rates of resin composites. Oper Dent 2013; 38(2): 226-33.

[41] Yu H, Wegehaupt FJ, Wiegand A, Roos M, Attin T, Buchalla W. Erosion and abrasion of tooth-colored restorative materials and human enamel. J Dent 2009; 37: 913-22.

[42] Bindl A, Mormann WH. An up to 5-year clinical evaluation of posterior in-ceram CAD/CAM core crowns. Int J Prosthodont 2002;15: 451-6.

[43] Uludag B, Usumez A, Sahin V, Eser K, Ercoban E. The effect of ceramic thickness and number of firings on the color of ceramic systems: an in vitro study. J Prosthet Dent 2007; 97: 25-31.

[44] Atay A, Oruc S, Ozen J, Sipahi C. Effect of accelerated aging on the color stability of feldspathic ceramic treated with various surface treatments. Quintessence Int 2008; 39: 603-9.

[45] Kelly JR, Nishimura I, Campbell SD. Ceramics in dentistry: historical roots and current perspectives. J Prosthet Dent 1996;75: 18-32.

[46] Celik EU, Aladag A, Turkun LS, Yilmaz G. Color changes of dental resin composites before and after polymerization and storage in water. J Esthet Restor Dent 2011; 23: 179-88.

[47] Ergucu Z, Turkun LS, Aladag A. Color stability of nanocomposites polished with one-step systems. Oper Dent 2008; 33: 413-20.

[48] Heydecke G, Butz F, Binder JR, Strub JR. Material characteristics of a novel shrinkage-free $\mathrm{ZrSiO}(4)$ ceramic for the fabrication of posterior crowns: official publication of the Academy of Dental Materials. Dent Mater 2007; 23: 785-91.

[49] Rinke S, Huls A. Copy-milled aluminous core ceramic crowns: a clinical report. J Prosthet Dent 1996; 76: 343-6.

[50] Federlin M, Krifka S, Herpich M, Hiller KA, Schmalz G. Partial ceramic crowns: influence of ceramic thickness, preparation design and luting material on fracture resistance and marginal integrity in vitro. Oper Dent 2007; 32: 251-60.

[51] Lawn BR, Pajares A, Zhang Y, et al. Materials design in the performance of all-ceramic crowns. Biomaterials 2004; 25: 288592.

[52] Thompson JY, Bayne SC, Heymann HO. Mechanical properties of a new mica-based machinable glass ceramic for CAD/CAM restorations. J Prosthet Dent 1996; 76: 619-23.

[53] Hervas-Garcia A, Martinez-Lozano MA, Cabanes-Vila J, BarjauEscribano A, Fos-Galve P. Composite resins: a review of the materials and clinical indications. Med Oral Patol Oral Cir Bucal 2006;11: E215-20.

[54] Perez CR. Alternative technique for class V resin composite restorations with minimum finishing/polishing procedures. Oper Dent 2010; 35: 375-9.

Received: April 12, 2013

Revised: July 30, 2013

Accepted: August 02, 2013

(C) Dirxen et al.; Licensee Bentham Open.

This is an open access article licensed under the terms of the Creative Commons Attribution Non-Commercial License (http://creativecommons.org/licenses/by-nc/3.0/) which permits unrestricted, non-commercial use, distribution and reproduction in any medium, provided the work is properly cited. 